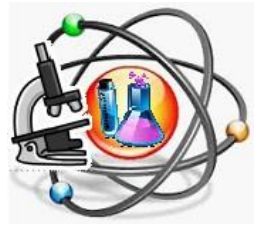

\title{
Analysis of Environmental Literacy Skill of Biology Teacher Candidates in Human and Environmental Courses
}

\section{Analisis Kemampuan Literasi Lingkungan Calon Guru Biologi Dalam Mata Kuliah Manusia dan Lingkungan}

\author{
Nike Anggraini ${ }^{1 *}$, Khoiron Nazip ${ }^{2}$, Puteri Kusuma Wardhani ${ }^{1}$, Dian Sri Andrian ${ }^{1}$ \\ ${ }^{1}$ Fakultas Keguruan dan IImu Pendidikan, Universitas Sriwijaya, Indonesia \\ ${ }^{2}$ Fakultas Teknik, Universitas Sriwijaya, Indonesia
}

This study examines the environmental literacy abilities of prospective Biology teacher students in the Biology Education Study Program, FKIP Sriwijaya University. The research subjects are Palembang and Indralaya class students who are teaching Human and Environmental Sciences Courses for the 2019/2020 academic year in Semester II. The skills measured in this study are aspects of Environmental Knowledge, Environmental Competence and Attitudes towards the environment formulated by the OECD and NAEE. The method used in this research is descriptive quantitative, with research subjects totaling 75 students. The technique of collecting data is through interviews, and surveys using an instrument sheet consisting of 20 multiple choice questions, 20 essays and 20 attitude scales. The data analysis technique used the SPSS 18 program. The test instrument used was modified from the Middle Schools Environment Survey/Instrument (MSELS/I) test questions and adapted to the physical conditions and environmental problems in the city of Palembang. The results showed that the prospective Biology teacher students were in the medium category for the Environmental Knowledge and Competence aspect, and got the high category for Environmental Attitudes.

ISSN 2540-9859 (online) Edited by:

Septi Budi Sartika

*Correspondence:

Nike Anggraini

anggraini.nike@pps.unsri.ac.id

Received:13-01-2021

Accepted: 21-05-2021

Published: 31-05-2021

Citation:

Anggraini $N$ et al (2021) Analysis of Environmental Literacy Skill of Biology

Teacher Candidates in Human and

Environmental Courses.

Science Education Journal (SEJ).

doi: $10.21070 /$ sej.v5i1.1169
Keywords: Environmental Literacy; Middle Schools Environment Survey/Instrument

Penelitian ini mengkaji tentang kemampuan literasi lingkungan yang dimiliki oleh mahasiswa calon guru Biologi Prodi Pendidikan Biologi FKIP Universitas Sriwijaya. Subjek penelitian yakni mahasiswa kelas Palembang dan Indralaya yang sedang mengampu Mata Kuliah Manusia dan Ilmu Lingkungan Tahun ajaran 2019/2020 di Semester II. Keterampilan yang diukur dalam penelitian ini yaitu aspek Pengetahuan Lingkungan, Kompetensi Lingkungan dan Sikap terhadap lingkungan yang dirumuskan oleh OECD dan NAEE. Metode yang digunakan dalam penelitian ini adalah deskriptif kuantitatif, dengan subjek penelitian berjumlah 75 orang siswa. Teknik pengumpulan data melalui wawancara, dan survei menggunakan lembar instrumen yang terdiri dari 20 soal pilihan ganda, 20 essai dan 20 skala sikap. Teknik analisa data menggunkan Program SPSS 18. Intrument tes yang digunakan memodifikasi dari soal tes Middle Schools Environment Survey/ Instrument (MSELS/I) dan disesuaikan dengan kondisi fisik dan permasalahan lingkungan di 
Kota Palembang. Hasil penelitian menunjukkan bahwa mahasiswa calon guru Biologi berada pada kategori sedang untuk aspek Pengetahuan dan Kompetensi Lingkungan, dan mendapatkan kategori tinggi untuk Sikap Lingkungan.

Kata Kunci: Literasi Lingkungan; Middle Schools Environment Survey/Instrument 


\section{PENDAHULUAN}

Banyaknya kerusakan lingkungan yang terjadi di masa ini, menjadikan lingkungan sebagai topik utama dalam Isu Global dunia. Banyak kita lihat terjadinya kerusakan lingkungan baik di negara maju ataupun negara-negara berkembang. Mulai dari banjir, kekeringan, pembalakan liar, serta penggunaan sumber daya alam secara berlebihan. Dahulu, banyak orang menduga bahwa kerusakan lingkungan disebabkan oleh faktor alam, akan tetapi semakin berkembangnya teknologi, orang-orang menyadari bahwa aktifitas manusia lebih memberikan dampak yang signifikan terhadap perubahan iklim dan lingkungan. Ditambah bahwa tidak semua aktifitas manusia disertai dengan rencana konservasi demi keberlanjutan di masa depan. Hal ini memperburuk kondisi lingkungan dunia.

Palembang merupakan salah satu kota metropolitan di Indonesia dan secara geografis terletak antara $2052^{\prime}$ sampai $305^{\prime}$ Lintang Selatan dan 1040 37' sampai 1040 52' Bujur Timur dengan ketinggian rata-rata 8 meter dari permukaan air laut. Dari segi kondisi hidrologi, Kota Palembang terbelah oleh Sungai Musi menjadi dua bagian besar disebut Seberang Ulu dan Seberang Ilir. Kota Palembang mempunyai 108 anak sungai. Terdapat 4 sungai besar yang melintasi Kota Palembang (Badan Pusat Statistik, 2013). Dengan kondisi geografis ini, Palembang dikenal sebagai kota air dimana sebagian besar daerah berupa rawa-rawa dan sungai. Semakin meningkatnya jumlah penduduk, Palembang tak lagi seperti Venesia yang mempertahankan karakternya. Melainkan seolah menjadi kota yang berdiri di dataran tinggi dengan bangunan berdinding tebal, dengan lantai yang langsung terhubung ke tanah. Yang artinya terjadi penimbunan yang menyebabkan wilayah rawa menyusut secara drastis. Bersamaan dengan itu, kondisi lingkungan Palembang semakin memperhatinkan dengan kondisi anak sungai Musi yang mengalami pendangkalan sehingga menyebabkan terjadinya banjir dimana-mana dan berdampak bagi spesies ikan belida (Notopterus chitala H.B) yang merupakan ikan khas Palembang hingga menjadi semakin langka (Anggraini, Nazip \& Andriani, 2021).

Banyak kajian yang membahas tentang prilaku manusia terhadap lingkungan sekitar. Salah satunya terkenal dengan sebutan manusia mentalis frontier. Yakni sekelompok manusia yang memiliki pikiran bahwa mereka bukanlah bagian dari lingkungan dan mampu untuk menjaga alam dengan cara menggunakan sumberdaya alam itu untuk memenuhi kebutuhan hidup mereka. Kelompok ini beranggapan bahwa sumber daya alam itu tidak terbatas dan tidak akan pernah habis. Penyimpangan prilaku seperti ini yang dapat menimbulkan krisis lingkungan (Chiras, 1991).

Mengarah pada kajian ini, maka dapat disimpulkan bahwa penurunan kualitas lingkungan dapat diubah dengan melakukan transformasi perilaku lingkungan yang tadinya bermental frontier menjadi perilaku berwawasan lingkungan. Dimana perilaku berwawasan lingkungan mengacu pada perbuatan manusia yang secara sadar mencintai lingkungan dengan dilandasi sikap tanggung jawab (responsibility)
(Steg, Dreijerink, \& Abrahamse, 2005).

Pemerintah menanggapi persoalan tentang lingkungan hidup dengan sangat serius dengan berkomitmen untuk menjaga lingkungan dan kerusakan lingkungan melalui Pendidikan. Melalui pendidikan, pemerintah berharap akan muncul suatu sikap peduli lingkungan yang akan memunculkan tahap-tahap kepedulian lingkungan dalam diri peserta didik sedari dini. Pendidikan lingkungan kemudian mulai diterapkan di dalam kurikulum yang terintegrasi dalam kurikulum 1984 sebagai Pendidikan Lingkungan Hidup (PLH) yang disisipkan dalam semua mata pelajaran. Baru kemudian pada kurikulum 2006 (KTSP), pendidikan lingkungan hidup mulai diberi peluang untuk menjadi mata pelajaran sendiri. Pendidikan Lingkungan merupakan suatu proses pengenalan nilai dan konsep untuk membangun sebuah pengetahuan, keterampilan dan sikap untuk memahami hubugan antar budaya dan lingkungan biofisi (Segara, 2015). Melalui Kementerian Pendidikan dan Kebudayaan bersama Kementerian Lingkungan Hidup mengembangkan Sekolah Peduli dan Berbudaya Lingkungan (SPBL) yang dikenal dengan program Adiwiyata (Azhar, Basyir, \& Alfitri, 2016).

Pemahaman peserta didik terhadap permasalahan lingkungan akan membuat setiap individu dapat memahami dan menafsirkan kondisi lingkungan sekitar mereka. Sehingga mereka dapat memutuskan tindakan yang tepat dalam mempertahankan, memulihkan serta meningkatkan kondisi lingkungan tersebut (Maguire, 1980). Tujuan utama dalam pendidikan lingkungan yakni membentuk manusia yang memiliki kecakapan literasi lingkungan yang baik, peduli terhadap masalah lingkungan dan dapat mengambil tindakan untuk menjaga lingkungan (Sriyati, 2015).

Hasil penelitian terhadap literasi lingkungan pernah dilakukukan oleh beberapa ahli, dimana hasil penelitian menyatakan bahwa literasi lingkungan pada peserta didik di sekolah masih sangat rendah. Ada banyak faktor yang menyebabkan hal ini terjadi, salah satunya yakni kurangnya minat untuk mengetahui dan mempelajari masalah-masalah lingkungan. Sebagai tiang utama dalam pendidikan, sudah tentu bahwa guru menjadi contoh pertama yang ditiru oleh para peserta didik (Abu-Hola, 2011; Cunningham, 2008; Sontay, Gökdere, \& Usta, 2015). Seorang guru harus memberikan stimulus dan contoh nyata kepada peserta didik dalam bersikap dan memecahkan permasalahan lingkungan. Sebagai mata pelajaran IPA, secara spesifik Biologi bukan hanya pengetahuan dasar berupa fakta atau konsep-konsep saja, melainkan suatu proses penemuan yang sangat erat kaitannya dengan lingkungan. Oleh karena itu, mengetahui kemampuan awal literasi lingkungan pada calon guru Biologi menjadi emergency untuk dilakukan sebelum mereka terjun ke lapangan menjadi Guru yang sebenarnya. Konsep literasi lingkungan dikembangkan dari konsep literasi sains. Status literasi lingkungan seseorang dapat diukur berdasarkan kriteria-kriteria literasi lingkungan, yaitu: kompetensi lingkungan, pengetahuan lingkungan dan sikap terhadap lingkungan (NAEE, 2011; PISA, 2016). 


\section{METODE PENELITIAN}

\section{Desain Penelitian}

Desain dalam penelitian ini yakni penelitian kuantitatif dengan metode penelitian deskriptif kuantitatif yang tidak memerlukan kelas kontrol (Fraenkel \& Wallen, 2012). Hal ini dilakukan karena peneliti tidak memberikan manipulasi atau pengubahan terhadap subjek penelitian, melainkan memberikan gambaran ukuran, jumlah atau frekuensi dengan pengumpulan dan pengolahan data apa adanya.

\section{Subjek Penelitian}

Subjek penelitian adalah mahasiswa Prodi Pendidikan Biologi FKIP Unsri yang berjumlah 75 orang yang terdiri dari kelas Palembang dan indralaya Tahun Ajaran 2019/2020. Teknik pengambilan sampel yakni Purposive sampling dengan memilih kelas/mahasiswa yang sedang mengambil mata kuliah Manusia dan Lingkungan di Semester II.

\section{Instrument Penelitian}

Instrument yang digunakan dalam penelitian ini berupa lembar instrumen yang terdiri dari 20 soal pilihan ganda, 20 essai dan 20 skala sikap. Tes literasi lingkungan mengadaptasi soal tes Middle Schools Environment Survey/ Instrument (MSELS/I), (Husamah, Miharja, \& Hidayati, 2020) dan disesuaikan dengan kondisi fisik dan masalah lingkungan di Kota Palembang. Distribusi instrument yang digunakan dalam penelitian ini dapat dilihat pada Tabel 1. Instrument soal essay digunakan untuk melihat kompetensi lingkungan yang dimiliki oleh para calon guru Biologi. Soal pilihan ganda untuk melihat pengetahuan lingkungan dan skala sikap digunakan untuk melihat sikap mereka terhadap lingkungan. Instrument tes yang digunakan sebelumnya telah di validasi dengan Anatest.

\section{[Table 1 about here.]}

\section{Teknik Analisa Data}

Hasil nilai rata-rata dari kedua kelas tersebut akan dilakukan uji beda menggunakan SPSS 18 untuk melihat perbedaan kedua nilai pada kelas tersebut.

\section{HASIL DAN PEMBAHASAN}

Data yang diperoleh yakni berupa angka dengan melihat rata-rata beda antara kedua kelas yang menjadi subjek penelitian. Data kuantitatif disajikan berdasarkan jawaban mahasiswa dalam menyelesaikan soal terkait literasi lingkungan. Soal-soal yang diberikan telah mengalami modifikasi sesuai dengan kondisi lingkungan Kota Palembang saat ini. Untuk menggali Pengetahuan lingkungan mahasiswa, soal telah dikelompokkan berdasarkan lima indikator yang dirumuskan OECD dan NAEE sehingga dapat memudahkan untuk menganalisis tiap indikatornya. Skor ratarata setiap indikator pengetahuan lingkungan disajikan dalam Gambar $\underline{1}$.

\section{[Figure 1 about here.]}

Gambar 1 memperlihatkan bahwa nilai rata-rata untuk setiap indikator pengetahuan lingkungan pada kedua kelas berada pada kategori sedang. Hampir di setiap kategori mahasiswa indralaya memiliki kategori yang tinggi dibanding mahasiswa kelas Palembang. Menurut pengamatan dosen pengampu mata kuliah ini, hal ini bisa didasari karena umumnya, mahasiswa kelas Palembang merupakan mahasiswa asal daerah yang memiliki pengetahuan literasi lingkungan yang cukup baik. Mereka terbiasa hidup berdampingan dengan lingkungan, lebih peka terhadap kondisi lingkungan dan banyak mengatasi permasalahan lingkungan dengan kearifan lokal. Berbeda dengan mahasiswa Palembang yang sebagian besar merupakan mahasiswa asal kota yang terbiasa hidup dengan fasilitas teknologi sehingga kurang peka terhadap kondisi lingkungan.

Berdasarkan indikasi dari kelima indikator tersebut, terdapat dua indikator yang harus menjadi perhatian utama dalam penelitian ini. Indikator tersebut yakni indikator sistem sosial, budaya dan politik serta indikator partisipasi dan tindakan strategis. Kedua indikator ini berada pada kategori rendah untuk kedua kelas tersebut. Hal ini dapat menjadi dasar utama pengembangan bahan perkuliahan pada materi lingkungan di dalam mata kuliah Manusia dan Lingkungan. Mengingat dalam mata kuliah ini sangat menekankan pada antropologis terhadap kondisi lingkungan.

Secara umum, hasil pada pengetahuan lingkungan menunjukkan bahwa mahasiswa calon guru pada kelas indralaya memiliki kemampuan yang lebih tinggi dibandingkan calon guru pada kelas Palembang. Berdasarkan hasil analisis menggunakan progaram SPSS, didapat T-value menunjukkan beda rata-rata sebesar 2,83 dan p-value sebesar 0,06, dimana artinya pengetahuan lingkungan mahasiswa calon guru biologi kelas indralaya berbeda signifikan dengan mahasiswa calon guru kelas palembang. Namun demikian, kemampuan calon guru biologi dalam indikator ekologis, pemahaman terkait isu lingkungan, dan solusi masalah lingkungan sudah cukup baik yang artinya mereka sudah mempunyai bekal dalam literasi lingkungan.

Pada Aspek Kompetensi lingkungan, dari keempat indikator yang telah dirumuskan OECD dan NAAEE kedua kelas berada pada kategori yang sama. Kedua kelompok calon guru biologi memiliki kemampuan yang sama pada ke-empat indikator yang ada dalam aspek kompetensi lingkungan. Sama seperti aspek sebelumnya, pada aspek kompetensi lingkungan juga terdapat 2 indikator berada pada kategori rendah. Indikator tersebut yakni mengidentifikasi dan menganalisi masalah lingkungan. Kedua indokator ini juga menjadi aspek utama dalam mengembangkan rencana perkuliahan. Kelemahan-kelemahan yang didapat dalam penelitian ini, menjadikan peneliti dapat lebih baik dalam mengembangkan 
bahan ajar perkuliahan manusia dan lingkungan. Skor ratarata pada aspek kompetensi lingkungan ditunjukkan pada gambar $\underline{2}$.

\section{[Figure 2 about here.]}

Selanjutnya untuk aspek sikap terhadap lingkungan, soal yang dibuat berdasarkan empat indikator yang juga dirumuskan oleh OECD dan NAEE. Skor nilai rata-rata untuk aspek sikap terhadap lingkungan dimuat dalam Tabel 2 .

\section{[Table 2 about here.]}

Hasil analisis dari Tabel 2, diketahui bahwa secara keseluruhan kedua kelompok mahasiswa calon guru Biologi untuk kedua kelas tersebut berada dalam kategori yang tinggi. Untuk beberapa indikator dan memiliki nilai yang berbeda cukup signifikan untuk indikator yang lain. Kategori tersebut yaitu pada indikator kepedulian dan niat untuk mengatasi lingkungan. Sedangkan untuk indikator ketertarikan dan tanggung jawab, didapat bahwa mahasiswa calon guru pada kelas indralaya memiliki nilai yang lebih tinggi dibandingkan kelas Palembang. Hasil ini juga didasari karena memang di FKIP Biologi UNSRI, sebagian besar mahasiswa daerah dengan akademik yang cukup baik berada di kelas Indralaya. Meskipun demikian, kedua kelompok ini memiliki sikap yang positif terhadap lingkungan.

Berdasarkan ketiga aspek yang telah dinilai, secara umum mahasiswa Calon guru Biologi Fkip Unsri memiliki kemampuan literasi lingkungan pada kategori sedang. Meskipun begitu, sikap mereka terhadap lingkungan sangat baik. Hasil ini sesuai dengan penelitian yang dilakukan (Ozgurler \& Cansaran, 2014) bahwasanya literasi lingkungan yang dimiliki calon guru di turkey memiliki sikap yang positif terhadap lingkungan tetapi tidak pada pengetahuan dan kompetensi lingkungan. Sebagai calon guru, perlu adanya usaha untuk menanamkan karakter cinta lingkungan pada diri mahasiswa. Agar mereka dapat mengimplementasikan dan menanamkannya kembali kepada peserta didik yang akan mereka ajar. Hal tersebut sesuai dengan pernyataan (Taufiqi, 2016), bahwa masa terbaik dimana penanaman karakter dilakukan yakni masa anak usia dini. Jika masa ini terlewatkan maka akan semakin sulit membentuk karakter yang baik, terutama sikap cinta lingkungan. Beberapa penelitian serupa menyatakan bahwa pembelajaran yang dapat memotivasi siswa lebih mengenal lingkungan dapat meningkatkan pengetahuan siswa tentang lingkungan hidup (Hasri \& Rachmawati, 2015).

\section{KESIMPULAN}

Kemampuan literasi lingkungan dilihat dari bagaimana Pengetahuan mereka terhadap lingkungan, kompetensi lingkungan dan cara bersikap terhadap lingkungan. Sebagai Calon guru Biologi, mahasiswa Pendidikan Biologi Kelas Palembang dan Indralaya secara keseluruhan berada pada kategori sama yakni pada kategori sedang. Akan tetapi kedua kelas tersebut memiliki sikap terhadap lingkungan dalam kategori tinggi. Hal ini kemudian menjadi acuan untuk peneliti dalam mengembangkan rencana dan bahan ajar perkuliahan Manusia dan Ilmu Lingkungan di masa yang akan datang. Penelitian selanjutnya dapat melakukan uji coba pendekatan-pendekatan yang bisa menjadi alternatif dalam perkuliahan.

\section{REFERENCES}

Abu-Hola, I. (2011). An Islamic Perspective on Environmental Literacy. Education.

Anggraini, N., Nazip, K., \& Andriani, D. S. (2021). Pengembangan Bahan Ajar Berorientasi Environmental Sustainability Education Berbasis Literasi Sains Dan Realitas Lokal Sumatera Selatan. PENDIPA Journal of Science Education, 5(3), 309-315.

Azhar, A., Basyir, M. D., \& Alfitri, A. (2016). Hubungan Pengetahuan Dan Etika Lingkungan Dengan Sikap Dan Perilaku Menjaga Kelestarian Lingkungan. Jurnal Ilmu Lingkungan. https://doi.org/10.14710/jil.13.1.36-41

Badan Pusat Statistik. (2013). Statistik Indonesia 2013. Katalog BPS.

Chiras, D. D. (1991). Environmental science: Action for a sustainable future (3rd ed.). Benjamin/Cummings Pub. Co; 3rd edition.

Cunningham, D. (2008). Literacy Environment Quality in Preschool and Children's Attitudes toward Reading and Writing. Literacy Teaching and Learning, 12(2), 19-36.

Hanna Suryana Hasri, Rini Rachmawati, S. (2015). Pembuatan Video Pembelajaran Lingkungan Hidup Berbasis Kondisi Lokal Untuk Meningkatkan Pengetahuan dan Sikap. Gadjah Mada. Retrieved from http://etd.repository.ugm.ac.id/home/detail_pencarian/81 351

Husamah, H., Miharja, F. J., \& Hidayati, D. A. (2020). Environmental literacy of islamic boarding school students: study in MA Bilingual-Sidoarjo, East Java, Indonesia. Prisma Sains: Jurnal Pengkajian Ilmu dan Pembelajaran Matematika dan IPA IKIP Mataram, 8(1), 57-68.

Fraenkel, J. R., Wallen, N. E., \& Hyun, H. H. (2012). How to Desigen and Evaluate Reserch in Education (8rd ed.). NEW YORK.

Maguire, M. (1980). Don Holdaway . The Foundations Of Literacy . Toronto : Ashton Scholastic , 1979 ., 107-110.

NAEE. (2011). Environmental Literacy Framework. Retrieved from https://naaee.org/ourwork/programs/environmental-literacy-framework

OZGURLER, S., \& CANSARAN, A. (2014). Graduate Students, Study of Environmental Literacy and Sustainable Development. International Electronic Journal of Environmental Education, 4(2), 71-83. 
https://doi.org/10.18497/iejee-green.31036

PISA. (2016). PISA 2015 Results in Focus. OECD.

Segara, N. B. (2015). Education For Sustainable Development (Esd) Sebuah Upaya Mewujudkan Kelestarian Lingkungan. Sosio Didaktika: Social Science Education Journal, 2(1), 22-30. https://doi.org/10.15408/sd.v2i1.1349

Sontay, G., Gökdere, M., \& Usta, E. (2015). A comparative investigation of sub-components of the environmental literacy at the secondary school level. Journal of Turkish Science Education. https://doi.org/10.12973/tused.10130a

Sriyati, S. (2015). Pengembangan Bahan Ajar Perubahan Lingkungan Berbasis Realitas Lokal dan Literasi Lingkungan. Jurnal Pendidikan Biologi, 12, 151-161.

Steg, L., Dreijerink, L., \& Abrahamse, W. (2005). Factors influencing the acceptability of energy policies: A test of VBN theory. Journal of Environmental Psychology. https://doi.org/10.1016/j.jenvp.2005.08.003

Taufiqi, H. M. (2016). Religious Parenting Hypnoteaching and Hypnotherapy for Brilliant Kids. Malang: Media Sutra Atiga.

Conflict of Interest Statement: Theauthorsdeclare that theresearch was conducted in the absence of any commercial or financial relationships that could be construed as a potential conflict of interest.

Copyright (c) 2020 Aziza and Wulandari. This is an open-access article distributed under the terms of the Creative Commons Attribution License (CC BY). The use, distribution or reproduction in other forums is permitted, provided the original author(s) and the copyright owner(s) are credited and that the original publication in this jour-nal is cited, in accordance with accepted academic practice. No use, distribution or reproduction is permitted which does not comply with these terms. 


\section{LIST OF TABLES}

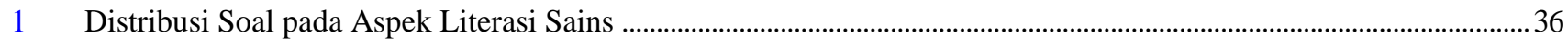

2 Skor rata-rata tiap indikator pada aspek sikap terhadap lingkungan untuk mahasiswa calon guru biologi FKIP Unsri

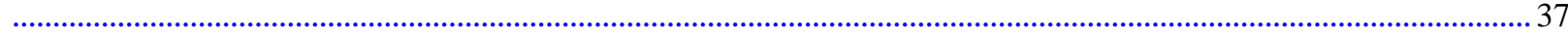


TABLE 1 / Distribusi Soal pada Aspek Literasi Sains

\begin{tabular}{|c|c|c|c|c|}
\hline Aspek Literasi Lingkungan & Komponen Spesifik & $\begin{array}{l}\text { Nomor } \\
\text { Soal }\end{array}$ & $\begin{array}{l}\text { Jumlah } \\
\text { Item }\end{array}$ & $\begin{array}{l}\text { Kisaran } \\
\text { Skor }\end{array}$ \\
\hline Pengetahuan Lingkungan & $\begin{array}{l}\text { Sistem fisik dan Ekologi } \\
\text { Partisipasi dan Tindakan Strategis } \\
\text { Isu Lingkungan } \\
\text { Sistem Sosbudpol } \\
\text { Solusi Masalah Lingkungan }\end{array}$ & $1-20$ & 20 & $0-20$ \\
\hline Kompetensi Lingkungan & $\begin{array}{l}\text { Menidentifikasi masalah lingkungan } \\
\text { Mengevaluasi dan membuat keputusan } \\
\text { Menganalisis masalah lingkungan } \\
\text { Menggunakan Bukti dan Pengetahuan }\end{array}$ & $21-35$ & 15 & $5-150$ \\
\hline Sikap Terhadap Lingkungan & $\begin{array}{l}\text { Keertarikan terhadap isu lingkungan } \\
\text { Kepedulian lingkungan } \\
\text { Tanggungjawab lingkungan } \\
\text { Niat mengatasi masalah lingkungan }\end{array}$ & $36-55$ & 20 & $20-100$ \\
\hline $\begin{array}{lr}\text { Ketetapan Range skor untuk ti } \\
\text { Pengetahuan } & : \text { Rang } \\
\text { Kompetensi } & : \text { Rang } \\
\text { Sikap } & : \text { Rang }\end{array}$ & $\begin{array}{l}\text { aspek } \\
=0-60 . \text { Rendah }=0-20 ; \text { Sedang }=21-40 ; \\
=0-60 . \text { Rendah }=0-20 ; \text { Sedang }=21-40 ; \\
=15-60 . \text { Rendah }=15-30 ; \text { sedang }=31-4\end{array}$ & & & \\
\hline
\end{tabular}


TABLE 2 | Skor rata-rata tiap indikator pada aspek sikap terhadap lingkungan untuk mahasiswa calon guru biologi FKIP Unsri

\begin{tabular}{lccc}
\hline \multirow{2}{*}{$\begin{array}{c}\text { Indikator Sikap Terhadap } \\
\text { Lingkungan }\end{array}$} & \multicolumn{3}{c}{ Mahasiswa Calon Guru Biologi } \\
\cline { 2 - 4 } & $\begin{array}{c}\text { kelas } \\
\text { Palembang }\end{array}$ & $\begin{array}{c}\text { kelas } \\
\text { Indralaya }\end{array}$ & Kategori \\
\hline $\begin{array}{l}\text { Ketertarikan Terhadap Isu } \\
\text { Lingkungan }\end{array}$ & 78 & 82 & Tinggi \\
\hline $\begin{array}{l}\text { Kepedulian terhadap } \\
\text { lingkungan }\end{array}$ & 74 & 80 & Tinggi \\
\hline $\begin{array}{l}\text { Tanggung jawab menjaga } \\
\text { lingkungan }\end{array}$ & 70 & 72 & Tinggi \\
\hline $\begin{array}{l}\text { Niat mengatasi masalah } \\
\text { lingkungan }\end{array}$ & 86 & 82 & Tinggi \\
\hline
\end{tabular}




\section{LIST OF FIGURES}

$1 \quad$ Diagram Perbedaan Nilai Rata-rata Indikator Pengetahuan Lingkungan ........................................................... 39

2 Diagram Perbedaan Nilai Rata-rata Aspek Kompetensi.... 


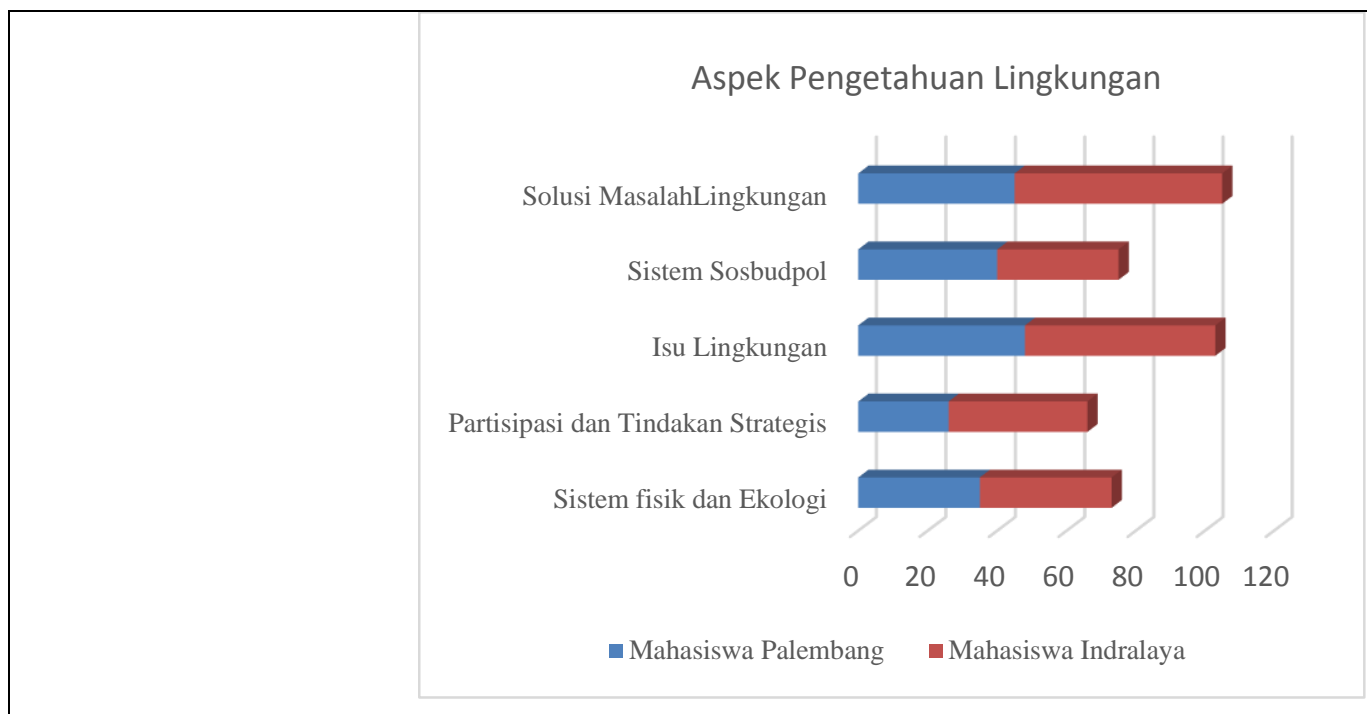

Figure 1/ Diagram Perbedaan Nilai Rata-rata Indikator Pengetahuan Lingkungan 


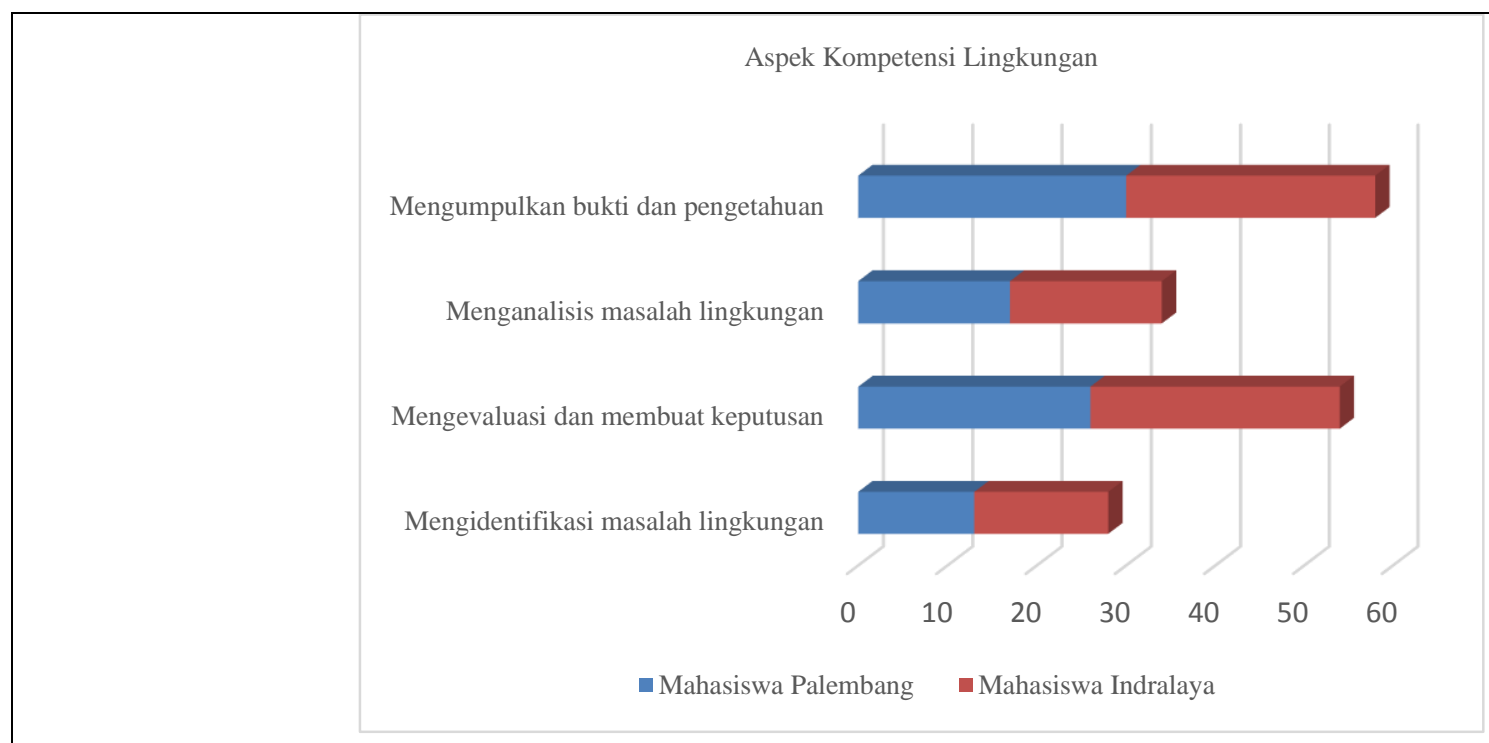

Figure 2/ Diagram Perbedaan Nilai Rata-rata Aspek Kompetensi Lingkungan 